\title{
Joining together to combat poverty: everybody welcome and needed
}

The International Poverty and Health Network was created in December 1997 after a series of conferences organised by the World Health Organisation (WHO) with the aim of integrating health into plans to eradicate poverty. Its formation was a response to the evidence of the persistent and growing burden of human suffering due to poverty. This is a worldwide (members from 46 countries) network of people and organisations from health, business, non-governmental organisations, and government who seek to influence policy to protect and improve the health of the world's poor, particularly the poorest in all countries. The network urges that a balance must be struck between social development and growth in income; between the human and financial dimensions of poverty; and between redistribution and market reforms. Its aspiration is to achieve a balance between biomedical and social approaches; between community based health development and a response to individuals; between prevention of disease, promotion of health, and treatment; and between physical and mental health. The more people who join the greater the likely impact of the network.

This editorial has already been published in the BMF (2000;320:1-2) and on Medscape and it is hoped that a version will appear in many other medical journals. International signatories appear on the BMF's website, www.bmj.com.

Despite overall dramatic increases in life expectancy in the past century, health professionals should be concerned about growing inequalities in health and wealth. ${ }^{1}$ The precipitous decline in life expectancy in Russia is a graphic example of how health may deteriorate as societies face sudden social and economic change accompanied by growing poverty. The gap in life expectancy for men between selected western European countries and Russia has widened from about three years in 1970 to around 15 in $1995 .^{2}$ Even among rich nations there are many examples of growing socioeconomic inequalities in health over the past 20 years. ${ }^{2}$ Health inequalities in Britain have just been declared the worst ever. ${ }^{3}$ The life expectancy gap between professional and unskilled workers is now 9.5 years for men and 6.4 years for women. Of particular concern is the fact that so many children are robbed of their physical and mental potential through poverty. ${ }^{4}$ Even in the US more than one in four children aged under 12 have difficulty obtaining all the food they need.

Ill health and poverty are mutually reinforcing and can generate a vicious cycle of deterioration and suffering. Ill health contributes directly to reduced productivity and sometimes to loss of employment. When it affects the main earner in poor families it has severe implications for economically dependent family members, particularly children. By definition, poor people have few reserves and may be forced to sell what assets they have, including land and livestock, or borrow at high interest rates, to deal with the immediate crisis precipitated by illness. Each option leaves them more vulnerable, less able to recover, and in greater danger of moving down the poverty spiral. In contrast, effective and accessible health services can protect the poor from spiralling into worsening economic problems. Poverty has many dimensions, lack of education, inadequate housing, social exclusion, unemployment, environmental degradation, and low income. Each of these diminishes opportunity, limits choices, undermines hope, and threatens health. Economic indicators focus primarily on income poverty, whereas health indicators provide a measure of the multidimensional nature of poverty. For this reason health should be the pre-eminent measure of the success or failure of development policies in the next century. In the 20 th century development was usually equated with economic growth, but the link between economic prosperity and health, a key component of human development, is not automatic. A recent World Bank study showed that income improvement caused about a fifth of the decline in mortality between 1960 and $1990 .^{5}$ Education of women and the generation and use of new knowledge were more important.

Health professionals strive to understand their patients' experience of illness and distress. As we share the frustration and anger of those whose health is undermined by poverty this understanding becomes part of a process of developing solidarity with disadvantaged individuals and communities. Once suffering is expressed, it becomes tangible and demands redress. This is fundamental to medicine and healing; it applies no less to social injustice. If we hear of suffering but do not work alongside the sufferer for redress, we abandon our task.

Over the next few years supporters of the network will strive to reduce the burden of ill health due to poverty in the following ways:

- Around 1.3 billion people live in absolute, grinding poverty on less than $\$ 1$ per day. ${ }^{6}$ This is despite the overall growth of the world economy, which doubled in the 25 years before 1998 to $\$ 24$ trillion

- Of the 4.4 billion people in developing countries nearly three fifths lack access to sanitation, a third do not have clean water, about a fifth have no health care, and a fifth do not have enough dietary energy and protein

- Economic disparities both within and between countries have grown, and in about 100 countries incomes are lower in real terms than they were a decade ago $^{7}$

- By 1995 the richest fifth of the world's population had 82 times the income of the poorest fifth

- The world's 225 richest people have combined wealth equivalent to the annual income of the poorest 2.5 billion (nearly half of the world's population). ${ }^{6}$ At the same time the world faces a growing scarcity of renewable resources from deforestation, soil erosion, water depletion, declining fish stocks, and lost biodiversity. The poor will be hit hardest by these problems 
- Promoting action for health locally, regionally, and nationally by working with sectors such as education, business, agriculture, and transport

- Building the evidence base on effective interventions to reduce inequalities in health and to determine how improved health can reduce poverty

- Facilitating exchange among health professionals in north and south about effective ways of working (such as WorldSpace's public health channel)

- Ensuring that education programmes for health professionals include information on the impact of socioeconomic inequalities on health and what they can do to reduce such inequalities

- Encouraging health professionals to work with local communities to improve the health of the poorest

- Monitoring trends in health inequalities and using the data to influence policy

- Engaging in strategic discussions with the International Monetary Fund, the World Bank, the WHO, and national governments to ensure that health is put at the centre of development, and to urge health impact assessments of all policies.

We invite others to join us in this endeavour. Why not you?

ANDY HAINES

Professor, Department of Primary Care and Population Sciences, Royal Free and University College Medical School, London, UK

IONA HEATH

General Practitioner and Chair, Intercollegiate Forum on Poverty and Health, Royal College of General Practitioners, London, UK

FIONA MOSS

Editor, Quality in Health Care

For more information please contact: International Poverty and Health Network (IPHN), Tel: 0207539 1570. Fax: 0207539 1580. drew.r@healthlink.org.uk (Roger Drew, UK); sochara@blr.vsnl.net (Thelma Narayan, India).
- Many African countries have total external debts that are more than $100 \%$ of their gross national product

- Although there has been progress in cancelling debt, only 22 of the 52 countries needing substantial or total debt reduction will actually see their annual payments reduced after the agreements made at the Cologne summit. ${ }^{8}$ Therefore much remains to be done, including monitoring how the World Bank and International Monetary Fund implement debt reduction ensuring that the economic reforms they recommend are focused on reducing poverty

- The announcement by the British Chancellor of the Exchequer just before Christmas that Britain would cancel the debts owed by the world's 25 poorest countries so long as the money saved was spent on poverty reduction and improving the health of the poorest is welcome. We hope other countries will follow

1 McCally M, Haines A, Fein O, et al. Poverty and ill health: physicians can and should make a difference. Ann Intern Med 1998;129:726-33.

2 Whitehead M, Diderichsen F. International evidence on social inequalities in health. In: Drever F, Whitehead M, editors. Health inequalities. London: Office for National Statistics, 1996.

3 Yamey G. Study shows growing inequalities in health in Britain. BMF 1999; 319:1453.

4 Unicef. The state of the world's children 1998. New York: Oxford University Press, 1998.

5 Wang J, Jamison D, Bos E, et al. Measuring country performance onhealth: selected indicators for countries. Washington, DC: World Bank, 1999.

6 United Nations Development Programme. Human development report 1998. New York: Oxford University Press, 1998.

7 United Nations Development Programme. Human development report 1996-7. New York: Oxford University Press, 1997.

8 Jubilee 2000 Coalition. Unfinished business. The world's leaders and the millennium debt challenge. London: Jubilee 2000 Coalition, 1999. 